\title{
Liability of Service Providers for Comments made on their Websites
}

\author{
The rights of freedom of speech and information versus the right to \\ honour in Spain in light of the Judgment of the European Court of \\ Human Rights in Delfi v. Estonia on 10 October 2013
}

\section{By Ramón Herrera de las Heras*}

This article takes a practical look at the issue of protection of the right to honour in social networks and websites in European and Spanish case-law. This is an analysis of the content of that right, the limits on the rights to freedom of information and speech, as well as regulatory changes needed to adjust current legislation.

Keywords: Right to honour, freedom of speech and information, websites, information service providers, civil liability.

\section{Introduction}

With the advent of the Internet in European homes in the early nineties, and more recently, with the emergence and rise of social networks, the spread of messages and opinions over the net has undergone a major transformation. What needed to be printed before by a means of a communication, usually a newspaper, or in any other format, e.g., brochures, can now be disseminated instantly and go viral in just a few minutes by reaching potential millions of users. The advantages in the field of knowledge, information and even freedom of speech are evident, but we cannot ignore the fact that it has also generated a number of problems which are very difficult to control, such as spreading messages in support of terrorists, harassment, especially of minors and public figures, or anonymous spread of rumours and false news. In this regard, the comedian Dieudonné tweeted recently in France 'Je me sens Charlie Coulibaly' [I feel like Charlie Coulibaly] in defence of the anti-Semitic expressions of the latter. In Spain, judicial authorities have already taken both criminal and civil action against this type of message. In fact, the National Court sentenced a young woman to one year in prison and seven of disqualification for offensive tweets against some members of the government such as, 'I promise to head-tattoo the face of anyone who shoots Rajoy and De Guindos.' In civil proceedings, the judgment of Trial Court No. 5 in Pamplona on 15 October 2012, is known for being one of the first related to this issue in our country. In this case, a municipal councillor of Pamplona was sentenced to delete tweets related to Uxue Barcos made on 18 March 2011, along with the

\footnotetext{
${ }^{*}$ Assistant Professor of Civil Law, Department of Law, University of Almería, Spain.
} 
corresponding compensation for breach of the latter's right to honour.

This is why this subject, spreading messages on websites or social networks in which a citizen's honour may be defamed or violated, generates some legal issues. We believe this quandary should be analysed to find out whether any legislative amendments are necessary to adapt Spanish and European legislation in force today to a reality very different from what existed at the time current legislation was passed. We must recognise that most of the EU member states have not adapted their legislation to these changes promptly, not even the EU itself.

It is true that some moves are currently being made by legislators who are attempting to establish specific regulations on the matter, but they have not yet seen the light. For instance, on 24 March 2015 the Spanish Congress of Deputies approved the Report of the Subcommittee for Study of Social Networks ${ }^{1}$ which proposed adapting traditional protection of honour by modifying two laws which, according to the report cited, have become obsolete: Organic Law 1/1982 of 5 May on civil protection of the right to honour, personal and family privacy and reputation, and General Law 7/2010 of 31 March on Audio-visual Communication.

But in spite of outdated legislation in this area as noted above, case-law progresses in the protection of those whose rights in this matter are infringed upon. In fact, the Judgment of the European Court of Human Rights of 10 October 2013 in Delfi v. Estonia is an important milestone analysed in more detail below.

\section{Freedom of Information and Speech v. Right to Honour}

The Declaration of Human Rights of 1789 states in Article 11 that 'The free communication of ideas and opinions is one of the most precious rights of man. Any citizen may therefore speak, write and publish freely, except what is tantamount to the abuse of this liberty in such cases as may be determined by Law.' This precept is reflected in the Spanish Constitution, which in Article 20.1 recognises and protects the right to freedom of speech and freedom of information, and therefore, to freely express and publicize thoughts, ideas and opinions. These two rights are closely related but not similar, since, as pointed out by the Supreme Court judgment of 18 February 2013, the right to information refers to the communication of facts which may be compared to objective data, whereas freedom of speech is a broader field, including opinions, which has a far wider scope, and involves not simply the communication of facts, but the issue of personal and subjective judgments, beliefs, thoughts and opinions ${ }^{2}$.

But as the Spanish Constitution enshrines these rights, the fourth paragraph of the aforesaid Article 20 provides that, 'These freedoms are

\footnotetext{
${ }^{1}$ Published in the Official Bulletin of the Parliament No. 643 of 9 April 2015.

${ }^{2}$ On freedom of expression, see Maillo (2011).
} 
limited by respect for the rights recognised under this Title, by the legal provisions implementing it, and especially by the right to honour (...).' This last fundamental right is defined by the Supreme Court following the classic Italian doctrine as 'Personal dignity as reflected in the consideration of others, ${ }^{3}$ and is included in our Constitution in Article 18.4, which states that 'The law shall restrict the use of data processing to the extent that the honour and the personal and family privacy of citizens as well as the full exercise of their rights are guaranteed.' We can thus understand, without fear of contradiction, that limitation on any abuse that may occur in social networks and the internet is protected by the Spanish Constitution. What it is definitely complicated is establishing the procedure to do so.

It is important to note here that the Spanish Constitution speaks clearly about limits, although case-law has established a weighting system for when the two fundamental rights clash. In such cases, prevalence is given to the rights of freedom of speech and information over the right to honour ${ }^{4}$. Therefore, as the Constitutional Court points out, special preponderant protection '....is subject to certain immanent external limits which this Court has been progressively refining. Among the immanent limits are the requirements for accuracy and general interest or public relevance of the information. In absence of the above two requirements, the Constitutional support of the freedom of information prevails. ${ }^{5}$ Thus the well-established and consistent case-law doctrine by which, in the frequent collision between the right to honour and freedom of information and speech, all of them of constitutional proclamation, two essential requirements need to concur for the prevalence of freedom of speech or information over the right to protection of honour: 1) That the information provided is about facts of general interest, with political, social or economic significance, and 2) that the information expressed is truthful, when the duty to verify its accuracy or verification has been observed or fulfilled. If the information provided is not true, or the contents are not of general interest, we would then be faced with clearly unlawful interference in the right to honour of the injured person.

However, as mentioned above, it is not, in my opinion, strictly a matter of prevalence, but of limits. Constitutional weighting techniques evaluate the circumstances of each case and the intensity and significance of each right to develop a rule that gives priority to one right over another and helps solve the case through its subsumption in that rule. ${ }^{6}$ I insist that such weighting should not be done as such, but for the content of freedom of speech and information in each case. If someone insults another for no reason, and with no relation to the case, it may be concluded that it does not fall within the content of the

\footnotetext{
${ }^{3}$ Supreme Court judgment of 4 November 1986.

${ }^{4}$ Unlawful interference in the right to honour is defined in Article 7.7 of Law 1/1982 which states that 'The ascription of facts or manifestation of value judgments through actions or expressions which in any way impair the dignity of another person, undermining their reputation or attacking their self-respect' will have such consideration.

${ }^{5}$ Judgment of the Constitutional Court of 24 February 2012.

${ }^{6}$ Echarri Casi (2013).
} 
rights of information and speech. Therefore, it is not weighting which is necessary, but the content of those rights in each case.

Although there is a fundamental right to information and speech, that right only goes so far as to avoid falsehoods in some cases and insults in others, ${ }^{7}$ e.g., calling someone a thief when it is not true does not mean that weighting would cause the right to honour to prevail over the right to information, because that falsehood is purely and simply not covered by the right to information, as it does not meet the abovementioned requirements. But that right ends when someone's right to honour is violated. ${ }^{8}$ The European Court of Human Rights (ECHR) has recently pronounced in this sense in its judgment of 12 June 2014 in Couderc Tt Hachette Filipacchi Associés v. France, which states that 'The exercise of freedom of speech implies duties and responsibilities, which also apply to the media, even when it concerns matters of great public interest. These duties and responsibilities may be particularly important when the reputation of a person cited by name is at risk and the rights of others may be infringed upon."

In line with this argument, the importance of differentiating between false and unverified news and a simple mistake made while investigating a news story that otherwise meets the minimal professional standards should be noted. For instance, if a website does not cite a source or show journalistic due diligence, it may also be considered a case of negligence. In fact, the Spanish Journalist Code of Ethics states in its Article 13 that 'The foundations of the information to be disseminated must be diligently laid, which means that journalists must check their sources and give persons affected an opportunity to tell their own version of the facts.' If the alleged information was not verified or the person involved was not contacted, the website would be held liable for such negligence. As the Constitutional Court states, '...truthfulness should be understood as the result of due diligence by the informant to verify the news according to professional guidelines appropriate to the circumstances of the case, even if the information may eventually be refuted or not be confirmed. 10 In this case, given that it deals with freedom of information, in accordance with the recent judgment of the Constitutional Court of 19 December 2013, 'Truthfulness, understood as due diligence in ascertaining the facts, determines the legitimacy of the right to information.'

\footnotetext{
${ }^{7}$ In this regard we should point out that Resolution 1165 of the Parliamentary Assembly of the Council of Europe on the right to respect for private life adopted on 26 June 1998 states that 'These rights are neither absolute nor in any hierarchical order, since they are of equal value.'

${ }^{8}$ Although there are many, if not most, authors who keep talking about preponderance. E.g., Buades Feliu (2014) who states that 'The protection of the right to honour must prevail over the freedom of expression when injurious or offensive phrases and expressions are used without reference to the ideas and opinions expressed and are unnecessary, since the system does not recognise the right to insult.'

${ }^{9}$ This is also included in Section 10 of the Convention for the Protection of Human Rights and Fundamental Freedoms.

${ }^{10}$ Judgment of the Constitutional Court of January 26, 2009.
} 
In the same vein, the Constitutional Court has stated that 'Due diligence in verifying the accuracy of the information is not satisfied by merely referring to unspecified sources, which under no circumstances exempts the author of the information from compliance with that duty. Reference to such sources of unidentified origin must be initially understood as insufficient to comply with due diligence, which certainly should not be construed as obligating the informant to disclose his sources of knowledge, but only prove that he has done something more than disregard the truthfulness or falseness of that information." 11

Along the same line, the Constitutional Court also pronounced in its judgment of 25 October 1999, in which it states that 'News must be diligently verified and supported by objective facts in order to qualify for constitutional protection.'

It should be pointed out that the Constitutional Court has denied such protection under the framework of freedom of information to those who '...by evading everyone's right to receive truthful information, transmit as true facts either mere rumours bereft of verification or mere inventions or insinuations whose accuracy has not been verified by the appropriate findings of a diligent professional. ${ }^{12}$

A particular case, but perhaps one of the most common, is related to public figures, and especially, politicians, since they are subject to very close scrutiny, which is how it should be. These people have to assume that being temporarily engaged in public life implies receiving criticism, sometimes excessively so, of their political work. But this right to criticism and to freedom of information and speech, under no circumstances legitimises insinuations, insults or the publication of false and absolutely untruthful news. Indeed, these insinuations are often made without information on the specific elements they are based on. This implies that the persons concerned cannot defend themselves against such insinuations by proving their untruthfulness, and are nevertheless defamed, and this is exactly what is meant by a declaration of value judgments through expressions damaging to one's dignity, reputation and self-respect. This agrees precisely with the consideration of unlawful interference with the right to honour, as defined by Article 7.7 of Organic Law 1/1982 of 5 May on civil protection of the right to honour, personal and family privacy and reputation, amended by Organic Law 10/1995 of 23 November on the Criminal Code ${ }^{13}$. It may also be concluded that insidious insinuations represent a violation of the right to honour, because they may not exceed their supposedly informative purpose by making it insulting, degrading or disproportionate, since as the Constitutional Court has reiterated, the Spanish Constitution does not recognise the hypothetical right to insult. ${ }^{14}$

\footnotetext{
${ }^{11}$ Judgment of the Constitutional Court of 16 January 1996.

12 Judgment of the Constitutional Court of 16 November 1996.

${ }_{13}^{13}$ Judgment of the Supreme Court of 24 September 2009.

${ }^{14}$ Among many others, the judgment of the Constitutional Court of 14 April 2008 or those of the Supreme Court of 18 February 2009 and 17 June 2009.
} 


\section{Liability of Service Providers of Websites and Authors of Messages in Social Networks}

The European Union started regulating this issue in Directive 2000/31/EC of the European Parliament and of the Council of 8 June 2000 on certain legal aspects of information society services, in particular electronic commerce, in the Internal Market. In its Article 4, this Directive establishes the liability of intermediary service providers, which as Tejedor Muñoz states, creates a system of liability waivers for intermediaries with some exceptions. ${ }^{15}$ Article 14 basically stipulates that service providers are not liable for damages caused to third parties, provided that two conditions are met. First, when the provider does not have '....actual knowledge of illegal activity or information', and second, '....acts expeditiously to remove or to disable access to the information.' The problem posed by the contents of the Directive is that it does not state what is meant by 'actual knowledge' or how long it should take for the data to be removed or its access prevented once it is known that the information is unlawful. ${ }^{16}$ Case-law has established some general criteria to bridge this gap, as discussed below.

The abovementioned Directive was transposed in Spain by the Law of Information Society Services of Spain (LSSICE), which is especially relevant to both the accountability system and the information itself and its transparency. Accordingly, the website's statement of legal terms should contain information on how user opinions are to be posted, whether there is any prior censorship or restraint, and what criteria are used to protect the rights of third parties. Service providers are therefore required to design an articulated system which prevents the publication of defamatory messages or that attribute criminal facts to persons or entities which may somehow violate their fundamental right to honour. Undoubtedly, a basic element is the need to identify the users who will be making the comments, as they should be the ones responsible for them. Otherwise the website will be held responsible for any unlawful interference that may occur. This was endorsed by the judgment of the European Court of Human Rights in Delfi v. Estonia on 10 October 2013. In too many websites, it is unnecessary to register to post a comment in order to identify, where appropriate, the person who may incur in injurious action.

It is true that some judgments have required websites to place a time limit on information posted so that any offensive comments can be removed. This communication, which can be made by such means as fax or email, would imply that if the website does not remove the existing comments promptly, it will be held co-responsible for them, either because not removing the comments implies tacit agreement with them, or by being aware of them and not restraining or removing them, it has incurred in a clear lack of due diligence. In my opinion, the removal of those comments once the person

\footnotetext{
15 Tejedor Muñoz (2011).

16 Tejedor Muñoz (2011).
} 
offended has reported them should not imply exemption from liability, but a way to mitigate it, since the injury has already been caused and it is evident that appropriate means to avoid it were not carried out.

Case-law is fairly strong in condemning those responsible for websites which lack means of control or identification. In fact, the Supreme Court judgment of 10 February 2011 agrees with the decision of the Provincial Court of Madrid of 30 October 2008, point 13, in which the defendants were found liable for comments appearing on their website despite the fact that the comments had not been written by them nor had they received any notification of their illegal content. Nonetheless, had they exercised due diligence, they would have been aware of them. As stated in the abovementioned judgment, 'Regardless of the above, that no prior decision has declared the content of the statements and the photograph on the website to be illegal, it is clear that in today's world of telecommunications and the ease and speed of data dissemination, referring the injured person to previous formal declaration of illegality when the interference with the right to honour is as noticeable as it is in the present case, would multiply the damage.'

It should be noted that service providers have the duty of care and collaboration imposed upon them. In fact, in the LSSICE, in its Article 11, a general duty of information is imposed on all service providers, who must provide information concerning their identity and location, as referred to in Article 10. This overview of who the service providers are and how they can be reached ensures that they can be identified in case of conflict. The obligation to remove any illegal content or information injurious to a person's honour can thus be met with diligence, and would help prevent its spread and extension over time. This claimant, as pointed out in the facts of the case, had submitted the corresponding request to have such comments removed to the address appearing on the website, but no response was received. In this same vein, the Spanish Supreme Court pronounced in its judgments of 10 February 2011 that 'The defendant did not exercise the minimum diligence required to facilitate direct contact by the injured party to stop publication of those oral statements and photographs which could be considered injurious, since he stored them at an inaccurate home address. Easy communication with him by the injured party was thus prevented."

The same Supreme Court judgment clearly established '...that three requirements must be met for exemption from liability, as stated in Article 16 of the LSSICE: a) The defamatory information must have been hosted on the server of an intermediary information service provider, b) the intermediary must not actually have been aware of the illegal nature of the stored data, or if so, removed them, c) the author may not have generated the data under the direction, authority or control of the intermediary. These conditions were met in the present case, so the judgment under appeal incurs in alleged infringement, as the cause for liability exclusion regulated by such provision has not yet been concurrently approved.' In this case, the appellant argued that 'Although he allows contents to be hosted on his server, in particular the claimant's messages, opinions and photograph, he did not participate in the 
selection, design or organisation of such information, but merely provided an absolutely neutral mediation service. So no responsibility for his behaviour should be attributed to him.' Such reasoning, as pointed out before, was dismissed by the Supreme Court.

The Supreme Court has provided a broad interpretation of the $1^{\text {st }}$ paragraph of Article 16 of Law 34/2002 (Judgment on Appeal No. 914/2006 of 9 December 2009, in addition to the one quoted above), as it unjustifiably reduces the possibilities of acquiring "actual knowledge" of the unlawful nature of the stored contents and correspondingly extends the scope of the exemption regarding the terms of harmonizing legislation, which requires effective knowledge, but without restricting suitable instruments for its acquisition. While Article 16 of Law 34/2002 allows this favourable interpretation of the Directive, as it does not limit the possibility of 'other means of actual knowledge that may be established', it should not be neglected that it attributes equal value to "actual knowledge" as to what is acquired by the service provider from suitable facts or circumstances to make effective comprehension of the reality concerned possible, whether directly or by logical inferences available to anyone. On this basis, that the Provincial Court attributes the same revealing value to the stored or linked contents as to its illegality is obvious in itself, as it does not depend on data or information which is not available to the intermediary. This Court considers that both the photograph and the expressions used constitute a flagrant interference with the claimant's right to honour, and states that no judgment declaring the contents thereof illegal was necessary. That conclusion is consistent with the doctrine expounded and leads to the conclusion of the defendant's lack of diligence in fulfilling the burden referred to in paragraph b) of the aforementioned Article 16 of Law 34/2002.

The European Court of Human Rights pronounced in this same sense in its important Judgment in the case of Delfi v. Estonia of 10 October 2013, which holds a digital communication medium liable for the violation of the right to honour by its readers in their comments posted about the news, which the medium published concealing the identity of the authors. In this sense, the defendant should have '...taken any action to promptly remove any offensive comment.' The ECHR stated that 'Although the website removed the comments when asked to do so, it did not have the necessary instruments to automatically prevent the publication of defamatory comments." This fully endorses the position expressed in this paper which supports the idea that the removal of the comments should not exempt from liability, but can mitigate it.

Thus as stated by the ECHR, when the medium allows readers to comment anonymously, it is "reasonable" to hold the editor responsible, since the news portal receives profits from the website, and comments are part of its contents. Therefore, the ECHR has definitely given priority to the right to honour, since 'It has been proven that the website did not act with due diligence'.

In this same sense and in a very similar case, the judgment of the Provincial Court of Badajoz of 17 September 2010 (280/2010) stated that, 'Just as the defendants could examine the contents of the messages to evaluate or analyse such suggestions, they certainly also had access to the messages, which 
far from being considered suggestions, contained the defamatory expressions which have led to this procedure. And if they allowed them to remain posted on the net when they could have removed them (...), they cannot now be exempted from liability by arguing, as the Public Prosecutor also did, that the messages were not posted directly by the defendants, and not otherwise essential within the framework of a civil procedure such as the present one to find out the specific individuals who submitted the messages.' With the same argument, the aforesaid judgment continues by stating that 'It is understood that the owners of the domain and the website would obviously examine its contents, and just as they knew of those suggestions and had them at their disposal, they also knew their defamatory contents, or at least had the possibility of knowing them. So the infringement of the right to honour caused by the website was committed by those who had the possibility to select the contents of what was transmitted and disseminated to the users.'

\section{Messages Which Violate the Right to Honour in Social Networks}

In accordance with Opinion 5/2009 on online social networking, social network services may be defined as 'Online communication platforms which enable individuals to join or create networks of like-minded users' ${ }^{17}$ According to a study conducted by the Interactive Advertising Bureau (IAB), there are over 14 million users of social networks in Spain, the most common of which are Facebook, Youtube and Twitter. ${ }^{18}$

The issue concerning this paper is different in social networks, since in order to make comments one must be registered and have an account in which the necessary identification data have been requested. How to ensure that the data entered by the users are true beforehand is a different matter. This is an issue to be addressed by experts, but it should include the possibility of recording with an electronic certificate in order to guarantee the accuracy of the data provided by the user. In this sense, the judgment of 13 January 1997 of the Constitutional Court states that 'If someone else's writing is published and the author's identity is unknown by the medium, it should be understood that the medium has accepted responsibility for its content.' The Supreme Court pronounced similarly in its judgment of 19 July 2004.

A different matter is whether social networks, especially Twitter and Facebook as the best known, can be considered media. I understand that the answer should be negative, among other reasons, because if not, it would imply that these networks should censor tens of thousands of messages per minute, which, apart from being impossible, would prevent these useful tools from having the sense of immediacy they currently have. It would make more sense

\footnotetext{
17 This opinion, approved on 12 June 2009, was prepared by the working group on data protection pursuant to Directive 95/46/EC, and is available at the following link: https://portal. uah .es/portal/page/portal/proteccion_datos/repositorio/wp163_es.pdf

18 This study is hosted at http://www.iabspain.net/wp-content/uploads/ downloads/2015/01/Es tudio_Anual_Redes_Sociales_2015.pdf
} 
to force these social networks to have a more secure user identification system which prevented the use of pseudonyms or the inclusion of false data. If they had this system available, it is obvious that those responsible for the offensive comments could not hide behind their anonymity. The desirability, within a few years, of the use of digital certificates being required to create a profile on these social networks is obvious.

In this field, the increasing number of court judgments in which the author is sentenced because of unlawful interference should be pointed out ${ }^{19}$. There is no variation in the concept of honour and the publication of expressions or messages which violate this right in social networks should not be given different treatment from any other context, except regarding the sentence, which is discussed further below. Once the authors of the interference have been identified, they must be reprimanded as forcefully as the authors of any other unlawful interference.

\section{Remedy for Damage Caused by Offensive Comments on Social Networks or Websites}

When the courts establish the obligations arising from conviction, apart from economic compensation, they always consider the effect of the information in order to make such measures proportionate, as far as possible, to the extent of the injury to honour. But in the case of social networks and websites, the effect of their comments, and therefore the damage to the holder of the right violated, is much broader than the one which may be caused by traditional media. Typically, in these cases, the information or comments shared on social networks go viral, which has two harmful consequences for the holders of rights. First, it is be very difficult to delete all comments or images in this regard, as they may be housed in the timelines of thousands of users or thousands of different servers. Second, they can spread to an extremely wide public. In fact, the reach of a single retweet or shared comment has an almost unlimited potential if we consider the number of the author's followers. Thus, in addition to economic compensation (which is not discussed here because it has been dealt with profusely by many other authors) the peculiarity of these cases is that the conviction and its compensation should be spread over the same social networks or websites. Moreover, the immediate removal of the messages is also obviously required. Thus Seville Court of First Instance No. 22, in Judgment No 235/2014, sentenced a user to publish said judgment on his social network every day for a month, as well as deleting the 47 tweets subject of the complaint, and which were considered damaging by the judge, from his Twitter profile.

\footnotetext{
19 Among others, the following: Judgment of Court of Instruction $\mathrm{N}^{\circ} 4$ of Segovia of 21 February 2011; Judgment of the Criminal Court of Vigo of 15 February 2013; Judgment of the Criminal Court of Córdoba of 7 February 2011; Judgment of the Court of Pamplona of 15 October 2012.
} 


\section{References}

Buades Feliu, J. (2014). "Algunas consideraciones de actualidad sobre el derecho al honor, la libertad de expresión y de información" [Some timely considerations on the right to honour, freedom of speech and information], in Diario La Ley, N. 8318 .

Echarri Casi, .F.J. (2013).’'Derecho al honour «versus» libertad de expresión e información [The right to honour versus freedom of speech and information]. $A$ propósito del juicio de ponderación", in Diario La Ley, n. 8096.

Serrano Maillo, M.I. (2011). "El derecho a la libertad de expresión en la jurisprudencia del Tribunal Europeo de Derechos Humanos: Dos casos españoles" [The right to Freedom of Speech in the jurisprudence of the European Court of Human Rights], in Teoría y realidad constitucional, $\mathrm{n}^{\circ} 28$.

Tejedor Muñoz, L. (2011). "Hosting o administradores de servicios de páginas web e intromisión al derecho al honor: La responsabilidad civil en el marco de la sociedad de la información" [Hosting or administrators if website services and interference with the right to honour: Civil responsibility in the framework of the Information Society], in Revista Crítica de Derecho Inmobiliario, n. 727:29012927. 
